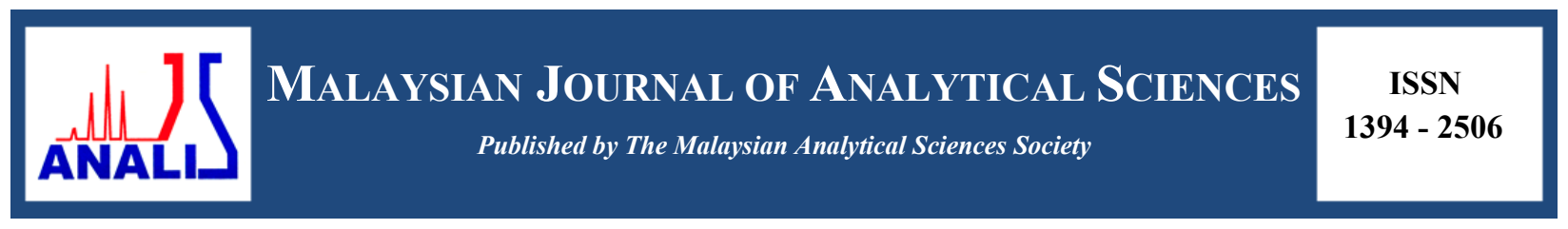

\title{
PERFORMANCE OF SOLAR PHOTOCATALYSIS AND PHOTO-FENTON DEGRADATION OF PALM OIL MILL EFFLUENT
}

\author{
(Prestasi Fotopemangkinan dan Degradasi Foto-Fenton Menggunakan Sinar Suria \\ ke atas Efluen Kilang Minyak Kelapa Sawit) \\ Devagi Kanakaraju $^{1 *}$, Nurul Liyana Binti Ahmad ${ }^{1}$, Noorfaezah Binti Mohd Sedik ${ }^{1}$, \\ Sylvester Gan Hsien Long ${ }^{1}$, Tay Meng Guan ${ }^{1}$, Lim Ying Chin ${ }^{2}$ \\ ${ }^{1}$ Department of Chemistry, Faculty of Resource Science and Technology, \\ Universiti Malaysia Sarawak, 94300 Kota Samarahan, Sarawak, Malaysia \\ ${ }^{2}$ School of Chemistry and Environment, Faculty of Applied Sciences, \\ Universiti Teknologi MARA, 40450 Shah Alam, Selangor, Malaysia \\ *Corresponding author: kdevagi@unimas.my
}

Received: 16 August 2016; Accepted: 5 April 2017

\begin{abstract}
Palm oil mill effluent (POME) contains significant amounts of organic matter, solids, and grease or oil, which requires appropriate treatment prior to being discharged into the environment. In this study, solar radiation was investigated as a possible source of photon in the solar $\mathrm{TiO}_{2}$ and $\mathrm{ZnO}$ photocatalysis, and solar photo-Fenton treatments to reduce the chemical oxygen demand (COD) in POME. The results indicated that solar photo-Fenton was more efficient in reducing COD levels compared to dark Fenton and indoor photo-Fenton. The highest removal was recorded at $89 \%$ in the presence of $1: 30$ ratio of $\mathrm{Fe}^{2+}: \mathrm{H}_{2} \mathrm{O}_{2}$ under acidic $\mathrm{pH}(\sim 2.8)$ after 3 hours of solar exposure. Increased concentrations of $\mathrm{H}_{2} \mathrm{O}_{2}$ have greatly influenced the COD removal. Additionally, solar $\mathrm{TiO}_{2}$ photocatalysis $\left(\mathrm{pH} 3.7 ; \mathrm{TiO}_{2}=0.1 \mathrm{~g} / \mathrm{L}\right.$ ) has outperformed solar photolysis and solar $\mathrm{ZnO}$ photocatalysis in reducing COD levels in POME. With successive increase of $\mathrm{TiO}_{2}$ from 0.02 to $0.1 \mathrm{~g} / \mathrm{L}$, the removal of COD had linearly increased from $54.3 \%$ to $88.5 \%$ after 5 hours of solar exposure. Based on the investigated conditions, the optimum $\mathrm{TiO}_{2}$ concentration of $0.1 \mathrm{~g} / \mathrm{L}$ was concluded. In conclusion, solar $\mathrm{TiO}_{2}$ photocatalysis and solar photo-Fenton can be applied as possible means to reduce the organic loads in POME.
\end{abstract}

Keywords: advanced oxidation process, organic matter, reduction, solar, titanium dioxide

Abstrak

Efluen kilang minyak kelapa sawit (POME) mengandungi jumlah bahan organik, pepejal dan gris atau minyak yang ketara yang memerlukan rawatan sesuai sebelum ia boleh disalurkan ke persekitaran. Dalam kajian ini, sinar suria dikaji sebagai salah satu sumber foton dalam fotopemangkinan $\mathrm{TiO}_{2}$ dan $\mathrm{ZnO}$ sinar suria dan rawatan foto-Fenton menggunakan sinar suria untuk mengurangkan keperluan oksigen kimia (COD) dalam POME. Keputusan kajian menunjukkan foto-Fenton menggunakan sinar suria adalah lebih berkesan dalam menurunkan COD berbanding dengan Fenton bercahaya dalam dan Fenton tanpa cahaya. Penyingkiran tertinggi yang dicatatkan ialah $89 \%$ menggunakan nisbah $\mathrm{Fe}^{2+}: \mathrm{H}_{2} \mathrm{O}_{2}$ sebanyak 1:30 dalam pH berasid ( 2.8) selepas pendedahan kepada sinar suria selama 3 jam. Peningkatan kepekatan $\mathrm{H}_{2} \mathrm{O}_{2}$ sangat mempengaruhi penyingkiran COD. Tambahan pula, fotopemangkinan $\mathrm{TiO}_{2}$ menggunakan sinar suria $\left(\mathrm{pH} \sim 3.7 ; \mathrm{TiO}_{2}=0.1 \mathrm{~g} / \mathrm{L}\right)$ menunjukkan prestasi yang lebih baik berbanding dengan fotolisis dan fotopemangkinan $\mathrm{ZnO}$ menggunakan sinar suria dalam mengurangkan kandungan COD dalam POME. Peningkatan $\mathrm{TiO}_{2}$ secara berturutan dari $0.02 \mathrm{ke} 0.1 \mathrm{~g} / \mathrm{L}$ meningkatkan penyingkiran COD secara linear daripada $54.3 \%$ ke $88.5 \%$ selepas pendedahan kepada sinar suria selama 5 jam. Berdasarkan keadaan eksperimen yang dikaji dapat dirumuskan bahawa kepekatan optimum $\mathrm{TiO}_{2}$ ialah sebanyak $0.1 \mathrm{~g} / \mathrm{L}$. Kesimpulannya, teknik fotopemangkinan $\mathrm{TiO}_{2}$ sinar suria dan Fenton sinar suria boleh digunakan untuk mengurangkan kandungan organik dalam POME. 
Kata kunci: proses pengoksidaan termaju, bahan organik, penurunan, sinar suria, titanium dioksida

\section{Introduction}

Malaysia is known as the world's largest palm oil exporter. The palm oil industry has made significant contribution to the country's economic revenue. The global demand for palm oil, particularly for crude palm oil and its related products, such as palm oil and palm kernel oil, is rapidly growing. Consequently, the palm oil industry is generating a significant amount of waste, namely palm oil mill effluents (POME). Approximately 44 million tons of POME was generated in 2008 in Malaysia [1]. Typically, raw POME is brownish in colour and contains elevated levels of organic matter, such as total solids $(405,000 \mathrm{mg} / \mathrm{L})$ and grease/oil $(6000 \mathrm{mg} / \mathrm{L})$, as well as high biochemical oxygen demand (BOD) $(25,000 \mathrm{mg} / \mathrm{L})$ and chemical oxygen demand (COD) $(50,000 \mathrm{mg} / \mathrm{L})[2,3]$. POME is also known to be highly acidic ( $\mathrm{pH} 3.8-4.5$ ) and biodegradable in nature. The open ponding system is currently used by $85 \%$ of palm oil mill operators, as the potential method to treat POME [1], due to its biodegradable nature. A ponding system comprises of a series of anaerobic, facultative and aerobic treatments. This type of system demands vast area of lands, requires lengthy treatment periods (up to 40-60 days) for effective treatments to be achieved, and it releases bad odour, despite its ease of operation $[4,5]$. A previous study has reported that this biological treatment process is rather inefficient in treating POME [2]. It contributes to various environmental issues due to the high loadings of BOD and COD, while a low $\mathrm{pH}$ of POME renders the conventional treatment technique inefficient.

In recent times, advanced oxidation processes (AOPs) have been considered as suitable methods to treat effluents in various wastewaters. AOPs are based on short-lived hydroxyl radicals $(\mathrm{HO} \bullet)$, which are powerful oxidizing agents that can decompose organic compounds in water [6]. AOPs, such as photocatalysis, ozonation, wet oxidation, and photo-Fenton have been documented to efficiently eliminate or mineralize organic pollutants in different types of wastewaters such as textile wastewater [7], pharmaceutical wastewater [8,9], and pulp mill wastewater [10]. In this study, titanium dioxide $\left(\mathrm{TiO}_{2}\right)$ and zinc oxide $(\mathrm{ZnO})$ photocatalysis, and photo-Fenton oxidation have been narrowed down as suitable methods to reduce the organic loads in POME. The photo-Fenton process uses Fenton reagents $\left(\mathrm{H}_{2} \mathrm{O}_{2}\right.$ and $\left.\mathrm{Fe}^{2+}\right)$ in the presence of light to produce $\mathrm{HO} \bullet$ radicals. This process involves the oxidation of ferrous ions $\left(\mathrm{Fe}^{2+}\right)$ to ferric ions $\left(\mathrm{Fe}^{3+}\right)$ in an acidic aqueous solution to produce $\mathrm{HO} \bullet$ radicals, which will trigger the oxidation of organic compounds. It is important to keep the solution at $\mathrm{pH} 3$ because the Fenton reaction works best in an acidic condition [11].

In the case of $\mathrm{TiO}_{2}$ and $\mathrm{ZnO}$ photocatalysis, photon illumination $(\lambda<400 \mathrm{~nm})$ onto the $\mathrm{TiO}_{2}$ and $\mathrm{ZnO}$ surfaces, of greater than or equal to the band gap energy, will result in the formation of electron-hole pairs. These pairs will be involved in the oxidative and reductive reactions with molecules present at/or near the surface of the semiconductor [12]. Both $\mathrm{TiO}_{2}$ and $\mathrm{ZnO}$ have similar band gap energy of $3.2 \mathrm{eV}$ [13]. Nonetheless, $\mathrm{TiO}_{2}$ is the most applied photocatalyst in various environmental applications, primarily due to its non-toxicity, low cost, and photostability. $\mathrm{ZnO}$, despite being highly photosensitive and absorbs a larger portion of the solar spectrum compared to $\mathrm{TiO}_{2}$, suffers from photocorrosion in acidic aqueous solution and the formation of $\mathrm{Zn}(\mathrm{OH})_{2}$ on its surface due to dissolution [13]. Thus, photocatalysis is of special interest since sunlight can be used as a photon source. Solar ZnO and $\mathrm{TiO}_{2}$ photocatalysis can be activated by sunlight of lower than $390 \mathrm{~nm}$, while photo-Fenton oxidation requires sunlight of up to $500 \mathrm{~nm}$. The degradation of organic pollutants using AOPs with sunlight as the energy source is advantageous in lowering costs. Previous studies on solar photo-Fenton [14], and solar $\mathrm{ZnO}$ and $\mathrm{TiO}_{2}$ photocatalysis $[15,16]$ have recognized the roles of these mechanisms in reducing or degrading organic compounds in wastewater effluents. Nonetheless, there remains a paucity of knowledge regarding the feasibility of these treatments on POME. Aris et al. [17] reported that solar photo-Fenton has resulted in a better COD and colour from biologically treated POME compared to ambient photo-Fenton. On the other hand, $\mathrm{TiO}_{2}$ photocatalysis was able to reduce the $\mathrm{COD}$ level of POME to $78 \%$ within 20 hours of irradiation [18].

This study aims to assess the efficiency of solar $\mathrm{ZnO}$ photocatalysis, solar $\mathrm{TiO}_{2}$ photocatalysis, and solar photoFenton in reducing the COD level of POME. The dependence of solar photodegradation rate on intrinsic parameters, such as $\mathrm{ZnO}$ and $\mathrm{TiO}_{2}$ concentrations, and the ratio of $\mathrm{Fe}^{2+}: \mathrm{H}_{2} \mathrm{O}_{2}$ was investigated. 


\section{Sample collection}

\section{Materials and Methods}

The POME samples used in this study were collected during the month of November 2014, from SALCRA Palm Oil Mill Plant located in Bau, Sarawak, Malaysia. The POME samples were collected from the cooling ponds of the palm oil mill, and stored in polyethylene bottles. The air-tight bottles were transported to the laboratory and kept refrigerated at $4{ }^{\circ} \mathrm{C}$ until further analysis. Characterization and solar photocatalytic oxidation treatments were performed using diluted POME.

\section{Characterization of palm oil mill effluents}

Diluted POME was used for water quality analysis. Distilled water was used to dilute $1 \mathrm{~mL}$ of POME effluent to $1000 \mathrm{~mL}$. The levels of biological oxygen demand $\left(\mathrm{BOD}_{5}\right)$, chemical oxygen demand (COD), total suspended solids (TSS), and dissolve oxygen (DO) were determined. All analyses were performed according to the Standard Methods of Water and Wastewater Treatment [19].

\section{Solar photodegradation of palm oil mill effluents}

POME solar photodegradation study was conducted on the ground floor of the Faculty of Resource Science and Technology, Universiti Malaysia Sarawak, Malaysia. All solar treatments were performed for $2-5$ hours on sunny days. Beakers filled with diluted POME and the required quantities of reagents were exposed to sunlight under continuous magnetic stirring. The beaker used for solar study was covered with a polyethylene wrap to avoid evaporation. A portable digital Lux meter (TEX 1335) was used to measure the intensity of sunlight. Temperature, $\mathrm{pH}$, and solar intensity were periodically measured during periods of solar exposure. The recorded sunlight intensity and temperature during all solar experiments had ranged from 30 to $180 \mathrm{Klux}$ and 30 to $38{ }^{\circ} \mathrm{C}$, respectively. The temperatures recorded during the solar photo-Fenton and solar $\mathrm{ZnO}$ and $\mathrm{TiO}_{2}$ photocatalysis had varied from 28 to $38{ }^{\circ} \mathrm{C}$. In the case of indoor photo-Fenton experiments, the recorded temperatures had varied from 23 to $24.5^{\circ} \mathrm{C}$. All experiments were performed in duplicate. COD reduction was calculated using Equation 1:

$$
\text { COD reduction }(\%)=\frac{\operatorname{COD}_{\text {initial }}-\mathrm{COD}_{\text {final }}}{\operatorname{COD}_{\text {initial }}} \times 100
$$

\section{Palm oil mill effluent concentration for treatment}

As the concentration of POME in the photocatalytic treatments would affect the overall COD removal efficiency, three dilution ratios (POME: water) were considered: 1:10, 1:100 and 1:1000. Diluted POME sample of 1:10 ratio (Figure 1a) appeared to be more brownish, thicker, and murkier compared to the other diluted samples (Figure 1b and 1c). To ensure the maximum performance of the photocatalysts or reagents in these treatments, and to ensure adequate light penetration, the dilution ratio of 1:1000 was used. At high pollutant initial concentrations, all catalytic sites are occupied [20].

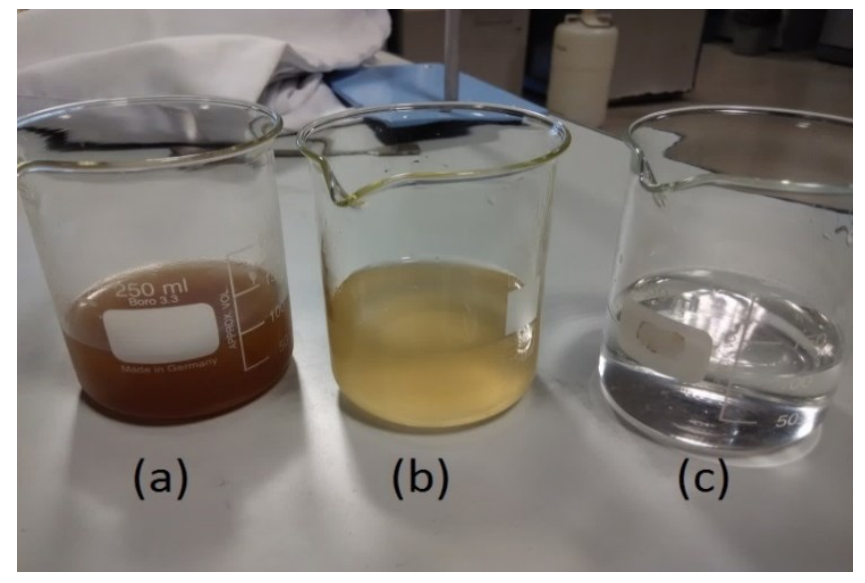

Figure 1. Photograph of diluted POME solutions (POME: water) (a) 1:10, (b) 1:100, and (c) 1:1000 


\section{Treatment of palm oil mill effluent using solar photocatalysis}

Solar $\mathrm{ZnO}$ and $\mathrm{TiO}_{2}$ photocatalysis were conducted by varying the concentrations of $\mathrm{TiO}_{2}$ and $\mathrm{ZnO}$ from 0.02 to 0.2 $\mathrm{g} / \mathrm{L}$ and 0.5 to $4 \mathrm{~g} / \mathrm{L}$, respectively in $150 \mathrm{~mL}$ of diluted POME (1:1000). The mixture of POME and photocatalyst (either $\mathrm{ZnO}$ or $\mathrm{TiO}_{2}$ ) was magnetically stirred for 30 minutes in a dark environment (covered with polyethylene wrap) to establish equilibrium between the two substances. Then, the reaction slurry in the beaker was uncovered before being exposed to direct sunlight. The beaker was magnetically stirred during solar exposure and sample collection was done at pre-determined intervals using a syringe. A parallel control experiment (without photocatalyst) was also conducted. Supernatant obtained via filtration was used for COD analysis.

\section{Treatment of palm oil mill effluent using solar photo-Fenton}

Indoor photo-Fenton (laboratory) treatments with ambient light and solar photo-Fenton treatments were performed to compare their efficiency in reducing COD levels in POME. The concentration of $\mathrm{Fe}^{2+}$ was kept constant, while the concentration of $\mathrm{H}_{2} \mathrm{O}_{2}$ was varied in the photo-Fenton experiments. Similar ratios of Fenton reagents, $\mathrm{Fe}^{2+}: \mathrm{H}_{2} \mathrm{O}_{2}$, which include 1:10, 1:20, 1:30, and 1:40, were investigated for both treatments. The $\mathrm{pH}$ of the solution mixture was kept in the range of $\mathrm{pH} 2$ to 3 by adding $\mathrm{H}_{2} \mathrm{SO}_{4}$ accordingly. Then, the mixture was continuous stirred in the laboratory to ensure homogeneity. It was subsequently exposed to sunlight. Samples were collected at fixed intervals. At the end of the solar exposure period, the $\mathrm{pH}$ of the sample was adjusted to range between $\mathrm{pH} 11$ and 12 by adding $\mathrm{NaOH}$ pellets. The sample was stirred again for 15 minutes before being left overnight to ensure the decomposition of $\mathrm{H}_{2} \mathrm{O}_{2}$. After the sample has stood overnight, filtration was performed, which was followed by COD analysis. A blank sample (POME only) was also exposed to sunlight alongside the photo-Fenton treatment. Similar procedures were applied for photo-Fenton treatments in the laboratory. In this case, the source of photon was from the visible light in the laboratory. The beaker used for dark Fenton treatment was wrapped with aluminium foil to prevent any form of light from penetrating the reaction mixture.

\section{Characterization}

Analytical grade $\mathrm{TiO}_{2}$ photocatalysts ( $99.8 \%$ trace metals basis, anatase) and $\mathrm{ZnO}$ were supplied by Sigma-Aldrich and Bendosen, respectively. The crystal phase of the $\mathrm{TiO}_{2}$ and $\mathrm{ZnO}$ samples were determined using the $\mathrm{X}$-ray Diffraction (XRD, PaNalytical X'pert Pro) method with $\mathrm{Cu} K \alpha$ radiation $(\lambda=0.154 \mathrm{~nm})$ in the scanning range of $2 \theta$ between $10^{\circ}$ and $80^{\circ}$, at a rate of $0.04^{\circ}$ per second. The accelerating voltage and applied current were $45 \mathrm{kV}$ and 40 $\mathrm{mA}$, respectively. Field emission scanning electron microscopy (FESEM) was performed using the Carl Zeiss, SUPRA 40VP Scanning Microscope to analyse the surface morphology of the samples. A low electron beam voltage of $5 \mathrm{kV}$ was used. Therefore, no coating was required prior to imaging.

\section{Characteristics of palm oil mill effluent}

\section{Results and Discussion}

Table 1 lists the results of $\mathrm{pH}, \mathrm{BOD}_{5}, \mathrm{COD}$, and TSS. POME is a thick brownish colloidal mixture of water, oil, and fine suspended solids. The $\mathrm{pH}$ of POME was found to be acidic, resulting from the organic acids produced during the fermentation process [5]. This indicates that raw POME is unsuitable to be directly discharged into water bodies as the permissible level set by DOE falls between 5 and 9 (Table 1). The BOD and COD values obtained in this study implied the elevated levels of organic matters in POME. A comparison between the obtained values and those outlined by the effluent discharge standard of the Environmental Quality Act 1974 [5], showed that these values had exceeded the permissible levels. The ratio of $\mathrm{BOD}_{5} / \mathrm{COD}$, which is normally used to express the biodegradability of wastewater, was calculated to determine whether POME could be biodegraded using biological treatments [21]. Clearly, the obtained $\mathrm{BOD}_{5} / \mathrm{COD}$ ratio of 0.10 (Table 1) implied that POME was not suitable to be biodegraded using biological treatments. The characterization of POME suggested that the open ponding system, as practiced by palm oil mill operators, has failed to reduce these parameters to comply with the discharge limits set by the Environmental Quality Act 1974 . Based on the obtained $\mathrm{BOD}_{5} / \mathrm{COD}$ ratio, this method is inefficient to improve the water qualities of POME to an acceptable level. Therefore, other treatments must be sought. 
Table 1. Characteristics of POME

\begin{tabular}{lcc}
\hline Parameter & Mean \pm SD & $\begin{array}{c}\text { Effluent discharged standard for crude palm oil } \\
\text { (Environmental Quality Act 1974)* }\end{array}$ \\
\hline $\mathrm{pH}$ & $4.85 \pm 0.05$ & $5-9$ \\
$\mathrm{BOD}_{3}, 30^{\circ} \mathrm{C}(\mathrm{mg} / \mathrm{L})$ & $7600 \pm 15.2$ & 100 \\
$\mathrm{COD}(\mathrm{mg} / \mathrm{L})$ & $73150 \pm 124.5$ & 1000 \\
$\mathrm{BOD}_{5} / \mathrm{COD}$ & 0.10 & $\mathrm{NA}$ \\
$\mathrm{TSS}(\mathrm{mg} / \mathrm{L})$ & $18000 \pm 5000$ & 400 \\
\hline
\end{tabular}

*Parameters Limit of Environmental Quality (Prescribed Premises) (Crude Palm Oil) (Amendment)

Regulation 1997, and NA: Not applicable

\section{Reducing chemical oxygen demand using solar heterogeneous photocatalysis}

Two types of photocatalyst, $\mathrm{TiO}_{2}$ and $\mathrm{ZnO}$ were applied during the solar heterogeneous photocatalytic treatment of POME. The effect of photolysis (without photocatalyst) was studied for two reasons: (i) to act as a control, and (ii) to confirm the contribution of solar heterogeneous photocatalysis towards reducing COD level. COD reduction, by means of photolysis, has ranged between 7 to $29 \%$, thus indicating that the presence of $\mathrm{TiO}_{2}$ or $\mathrm{ZnO}$ is crucial to reduce the COD level in POME.

An optimum concentration of photocatalyst under studied experimental conditions is an important factor towards achieving efficient removal of COD. Thus, the effect of $\mathrm{TiO}_{2}(0.02$ to $0.2 \mathrm{~g} / \mathrm{L})$ and $\mathrm{ZnO}(0.5$ to $2.0 \mathrm{~g} / \mathrm{L})$ concentrations on the reduction of COD was studied. The same experimental conditions were applied for both photocatalytic treatments, where $150 \mathrm{~mL}$ of diluted 1:1000 POME was exposed under sunlight for 5 hours. The optimum concentration of photocatalyst was then fixed for other parameters studied. Figure 2 shows the percentage of COD reduction after 5 hours of solar $\mathrm{TiO}_{2}$ photocatalysis. As expected, the percentage of COD reduction was increased from 54.3 to $88.5 \%$ concomitantly with the increased amount of $\mathrm{TiO}_{2}$ from 0.02 to $0.1 \mathrm{~g} / \mathrm{L}$. However, further increase of $\mathrm{TiO}_{2}$ to $0.2 \mathrm{~g} / \mathrm{L}$ has yielded only $40 \%$ of COD reduction. Under the studied experimental conditions, $0.1 \mathrm{~g} / \mathrm{L}$ of $\mathrm{TiO}_{2}$ has led to a maximum reduction of $88.5 \%$ of $\mathrm{COD}$ (Figure 2). $\mathrm{TiO}_{2}$ concentrations of higher than the optimum value $(0.1 \mathrm{~g} / \mathrm{L})$ could increase the opacity of the suspension due to the excess amount of photocatalyst. Furthermore, penetration of solar radiation could have been impeded by the excess catalysts [22], contributing to the retardation of COD reduction. With $0.1 \mathrm{~g} / \mathrm{L}$ of $\mathrm{TiO}_{2}, \mathrm{COD}$ was reduced from $73,150 \mathrm{mg} / \mathrm{L}$ to $8,000 \mathrm{mg} / \mathrm{L}$ after 5 hours of solar exposure (Figure 3).

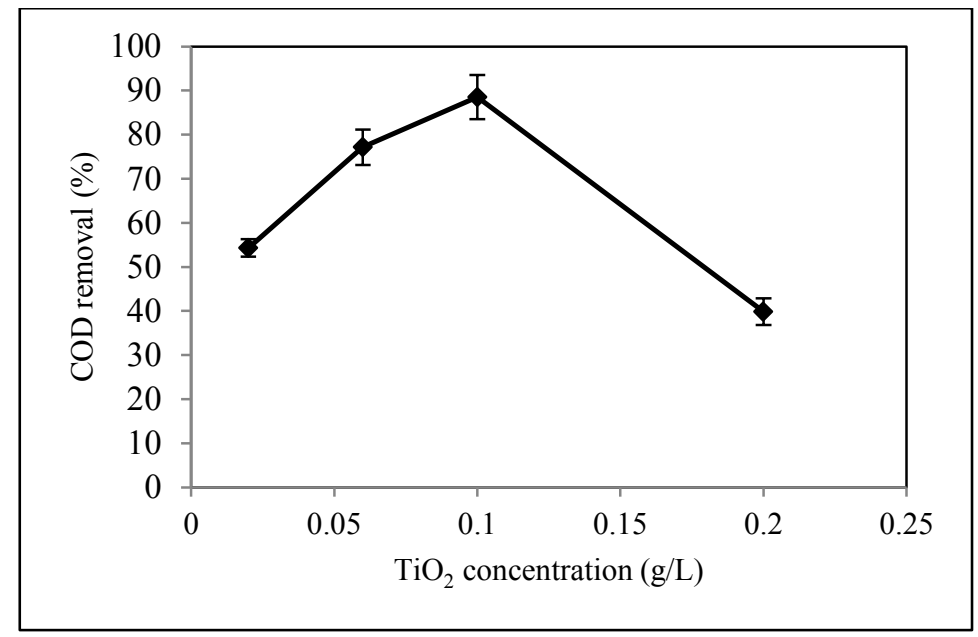

Figure 2. Effect of $\mathrm{TiO}_{2}$ concentration on COD reduction efficiency using solar $\mathrm{TiO}_{2}$ photocatalysis (error bars indicate standard deviation) 


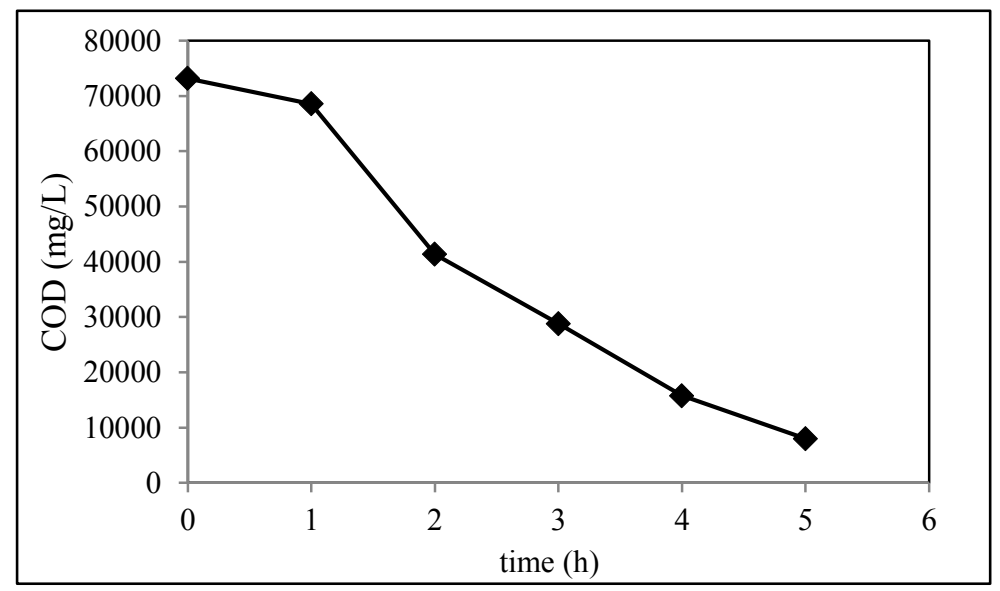

Figure 3. Reduction of COD with the optimum concentration of $\mathrm{TiO}_{2}(0.1 \mathrm{~g} / \mathrm{L})$ using solar $\mathrm{TiO}_{2}$ photocatalysis

In the case of $\mathrm{ZnO}$, the percentage of COD reduction has increased from 26.3 to $60.5 \%$ with increased $\mathrm{ZnO}$ concentration, from 0.5 to $2 \mathrm{~g} / \mathrm{L}$ (Figure 4). Further increase of $\mathrm{ZnO}$ concentration to $4 \mathrm{~g} / \mathrm{L}$ has resulted in the declining percentage of COD reduction to $36.6 \%$. The reasons elucidated for $\mathrm{TiO}_{2}$ photocatalysis could also be applied to the phenomenon observed during the $\mathrm{ZnO}$ photocatalysis. When the performances of $\mathrm{ZnO}$ and $\mathrm{TiO}_{2}$ photocatalysis were compared based on the effect of photocatalyst concentration on COD reduction, the latter has demonstrated better reduction efficiency under the investigated experimental conditions. The higher percentage of COD reduction of $88.5 \%$ was achieved with a low $\mathrm{TiO}_{2}$ concentration $(0.1 \mathrm{~g} / \mathrm{L})$. In contrast, $2 \mathrm{~g} / \mathrm{L}$ of $\mathrm{ZnO}$ was required to obtain the maximum percentage of COD reduction of $60.5 \%$. Several studies have reported that $\mathrm{ZnO}$ photocatalysis had performed better than $\mathrm{TiO}_{2}$ photocatalysis for pollutant degradation $[16,23]$ because $\mathrm{ZnO}$ can absorb a larger fraction of the solar spectrum compared to $\mathrm{TiO}_{2}$. However, in this study, the performance of $\mathrm{TiO}_{2}$ was superior to $\mathrm{ZnO}$.

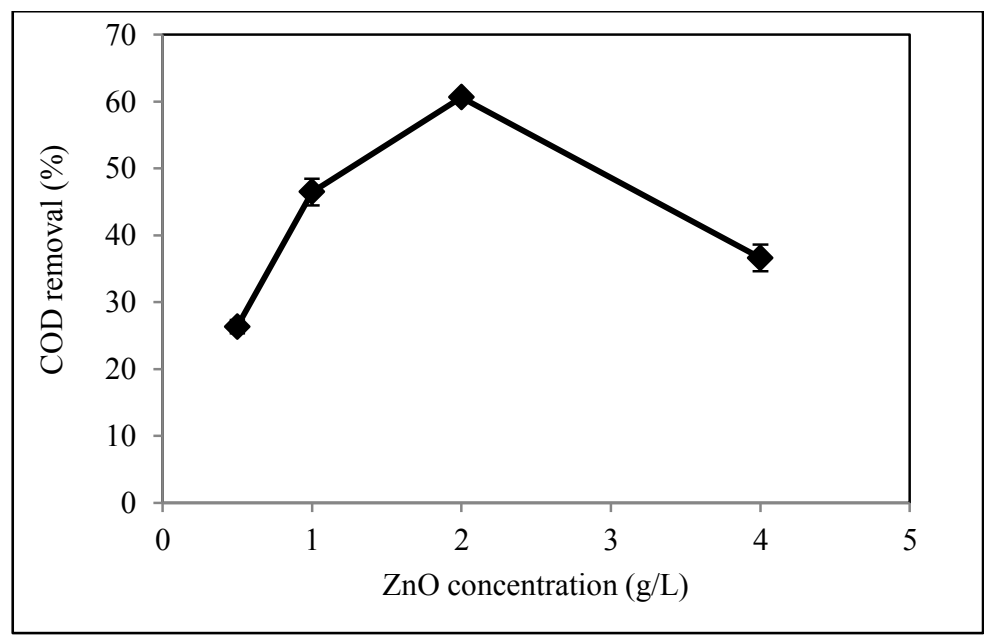

Figure 4. Effect of $\mathrm{ZnO}$ concentration on $\mathrm{COD}$ reduction efficiency using solar $\mathrm{ZnO}$ photocatalysis (error bars indicate standard deviation)

The performance of photocatalysts in degrading organic matter is known to be closely linked to their synthetic nature. The XRD patterns in Figure 5 clearly corresponded to the typical pure anatase $\mathrm{TiO}_{2}$. The existence of strong crystalline peaks at $2 \theta$ values of $25.3^{\circ}, 37.6^{\circ}, 48.0^{\circ}, 53.9^{\circ}$, and $54.9^{\circ}$, which corresponded to the crystal planes of 
(101), (004), (200), (105), and (211), respectively, were indicative of pure anatase $\mathrm{TiO}_{2}$ (Figure 5a). As for $\mathrm{ZnO}$, the crystalline peaks at $2 \theta$ values of $31.8^{\circ}, 34.4^{\circ}, 36.2^{\circ}$, and $47.5^{\circ}$ corresponded to the crystal planes of (100), (002), (101), and (102), respectively. These peaks were indicative of the predominant crystalline phase of ZnO (Figure 5b). FESEM images were also acquired for the commercial $\mathrm{TiO}_{2}$ and $\mathrm{ZnO}$, as shown in Figure 6. Figure 6a shows the surface of $\mathrm{TiO}_{2}$ to be smooth and spherical in shape, with slightly varied particle sizes. Meanwhile, $\mathrm{ZnO}$ particles were predominantly rod-shaped (Figure $6 \mathrm{~b}$ ). Irregular sizes of $\mathrm{ZnO}$ particles in spherical and rectangular shapes can also be observed.
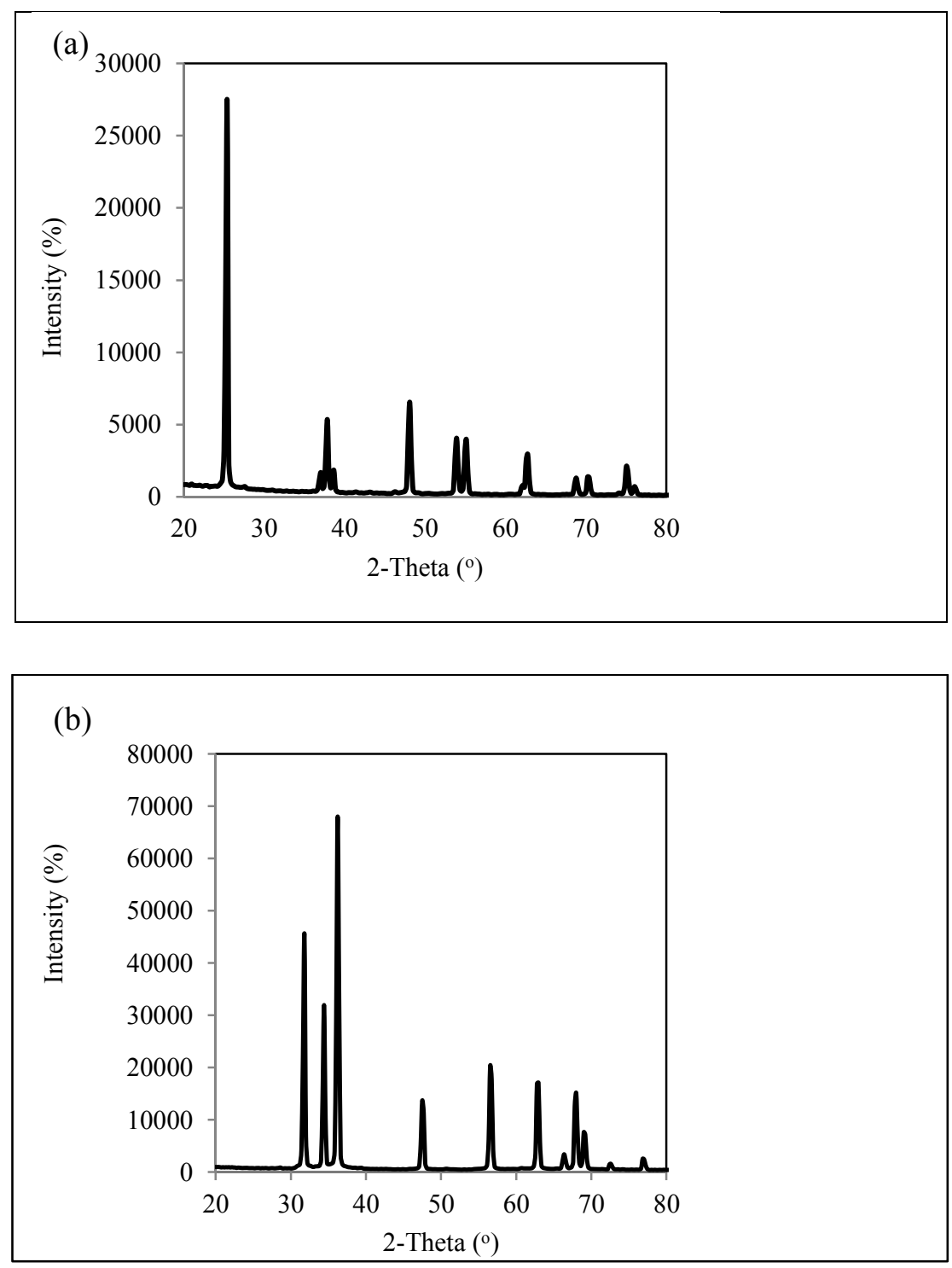

Figure 5. Comparison of XRD patterns between commercial: (a) $\mathrm{TiO}_{2}$, and (b) $\mathrm{ZnO}$ 

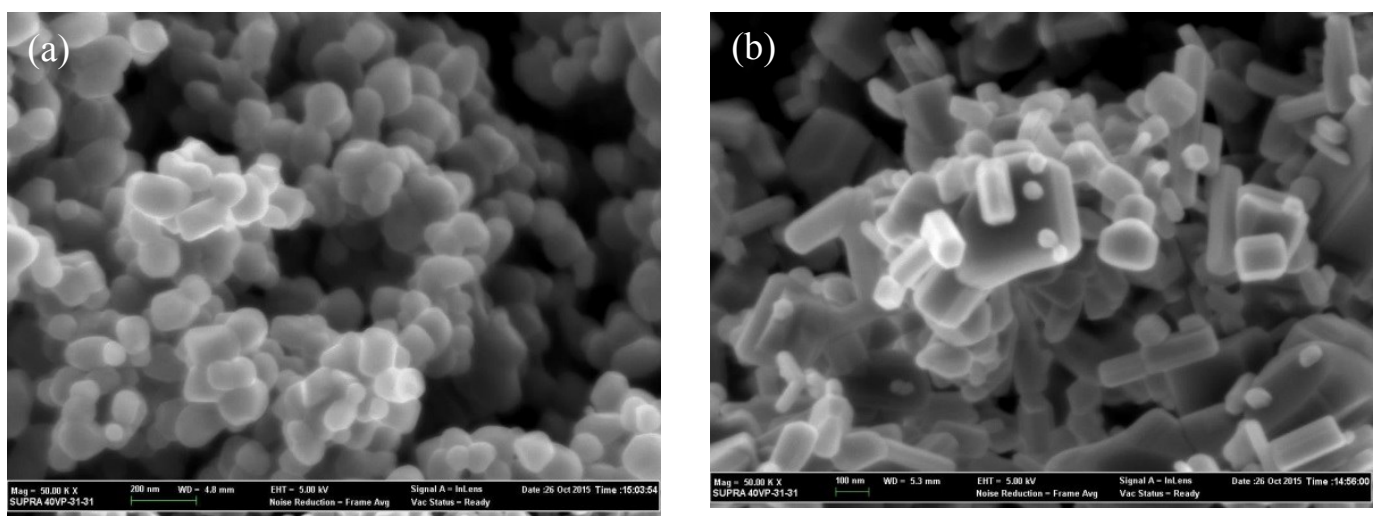

Figure 6. FESEM images of commercial: (a) $\mathrm{TiO}_{2}$, and (b) $\mathrm{ZnO}$

High crystallinity and non-porosity of both $\mathrm{ZnO}$ and $\mathrm{TiO}_{2}$ could have contributed to the oxidation or mineralization of the organic matter in POME. The Brunauer-Emmett-Teller specific surface areas $\left(S_{\mathrm{BET}}\right)$ for $\mathrm{TiO}_{2}$ and $\mathrm{ZnO}$ were $55 \mathrm{~m}^{2} / \mathrm{g}$ and $25 \mathrm{~m}^{2} / \mathrm{g}$, respectively. The average particle size of $\mathrm{TiO}_{2}$ could also be estimated from the $S_{\mathrm{BET}}$ by assuming that all particles have the same spherical size and shape. The particle size, $D$ is given by Equation 2 [24]:

$$
\mathrm{D}=\frac{6000}{\mathrm{~S}_{\mathrm{BET}} \times \rho}
$$

where $\rho$ is the true density for $\mathrm{TiO}_{2}$, which in this study, was $4.2 \mathrm{~g} / \mathrm{mL}$ and the estimated particle size was $26 \mathrm{~nm}$. However, estimating the particle size of $\mathrm{ZnO}$ from Equation 2 would be inaccurate as $\mathrm{ZnO}$ has distinct irregular shapes, ranging from rod to rectangular. By using the Image $\mathrm{J}$ software, the particle size of $\mathrm{ZnO}$ was estimated to be $300-400 \mathrm{~nm}$, with some $46-50 \mathrm{~nm}$ spherical particles. In this study, COD removal efficiencies could largely be attributed to fine spherical nanoparticles that have higher surface areas compared to the larger particles. With its smaller particle size, $\mathrm{TiO}_{2}$ could absorb more photon and subsequently, more active sites were created, where more hydroxyl radicals were induced to enhance COD removal. In contrast, $\mathrm{ZnO}$ has lower absorption potential due to its relatively larger particle size. A similar observation was also made by Rojviroon et al. [25] and Vineetha et al. [26].

The performance of solar photocatalytic reaction is greatly influenced by $\mathrm{pH}$ and the concentration of catalyst [27]. In this study, solar $\mathrm{ZnO}$ and $\mathrm{TiO}_{2}$ photocatalysis were performed without any $\mathrm{pH}$ adjustment. POME is known to be very acidic in nature. In this study, $\mathrm{pH}$ adjustment was not considered as it will increase the cost of treatment. Nonetheless, $\mathrm{pH}$ readings were recorded during sample collection to investigate whether there was any direct relationship between the $\mathrm{pH}$ of the suspension and $\mathrm{COD}$ reduction. The $\mathrm{pH}$ values of the collected samples during this treatment ranged between 1.2 and 4.9. The recorded mean $\mathrm{pH}$ for the highest percentage of COD reduction, which was attained using $0.1 \mathrm{~g} / \mathrm{L} \mathrm{TiO}_{2}$, was at 3.68 . Higher $\mathrm{TiO}_{2}$ loading of $0.2 \mathrm{~g} / \mathrm{L}$ had not only resulted in a very acidic $\mathrm{pH}(\sim 1.2)$, it had also produced the lowest percentage of COD reduction. The aggregation of $\mathrm{TiO}_{2}$ particles at $0.2 \mathrm{~g} / \mathrm{L}$ could have reduced the ability of the suspension to absorb light [24], thus affecting the percentage reduction of COD. In addition, $\mathrm{TiO}_{2}$ photocatalytic oxidation of POME may also produce other intermediary or degradation products, which could also have been acidic in nature, and directly affected COD reduction. Hence, this study has shown that COD reduction in POME is possible by means of solar $\mathrm{TiO}_{2}$ photocatalysis without any prior $\mathrm{pH}$ adjustments and a small amount of $\mathrm{TiO}_{2}$.

\section{Reduction of chemical oxygen demand by solar photo-Fenton}

Solar photo-Fenton treatment was conducted by varying the $\mathrm{Fe}^{2+}: \mathrm{H}_{2} \mathrm{O}_{2}$ ratio to investigate its effect on COD reduction efficiency. Experiments were conducted by varying the concentrations of $\mathrm{H}_{2} \mathrm{O}_{2}$ in difference ratios of $\mathrm{Fe}^{2+}: \mathrm{H}_{2} \mathrm{O}_{2}(1: 10,1: 20,1: 30$, and 1:40). A predetermined volume of $\mathrm{NaOH}$ was added to the samples at the end of the photo-Fenton treatments. The $\mathrm{NaOH}$ will lead to the formation of iron precipitate, $\left(\mathrm{Fe}(\mathrm{OH})_{3}\right)$, which could accelerate the decomposition of $\mathrm{H}_{2} \mathrm{O}_{2}$. The precipitation of $\mathrm{Fe}(\mathrm{OH})_{3}$ was observed to be slightly reduced in samples treated via photo-Fenton. To avoid the interference of excess $\mathrm{H}_{2} \mathrm{O}_{2}$ in the COD analysis, titration with potassium 
permanganate was conducted to ensure the complete decomposition of excess $\mathrm{H}_{2} \mathrm{O}_{2}$. In the presence of $\mathrm{H}_{2} \mathrm{O}_{2}$, manganese(VII) was reduced to colourless manganese(II), as shown in Equation 3.

$$
2 \mathrm{KMnO}_{4}+5 \mathrm{H}_{2} \mathrm{O}+3 \mathrm{H}_{2} \mathrm{SO}_{4} \leftrightarrow \mathrm{K}_{2} \mathrm{SO}_{4}+2 \mathrm{MnSO}_{4}+8 \mathrm{H}_{2} \mathrm{O}+5 \mathrm{O}_{2}
$$

Blank diluted POME (1:1000) was added with $\mathrm{FeSO}_{4} \cdot 7 \mathrm{H}_{2} \mathrm{O}$ and $\mathrm{H}_{2} \mathrm{O}_{2}$ separately (without both reacting simultaneously) to determine the effect of the addition of these reagents on COD reduction. POME samples that contained $\mathrm{H}_{2} \mathrm{O}_{2}$ had turned bright red immediately after the addition of Ferroin indicator, thus no titration was performed on these samples. POME samples with $\mathrm{FeSO}_{4} \cdot 7 \mathrm{H}_{2} \mathrm{O}$ had required similar amount of ferrous ammonium sulphate as the blank sample during titration. This observation implies that the addition of these reagents did not affect the experimental results of COD reduction in the photo-Fenton treatment.

The amount of $\mathrm{Fe}(\mathrm{II})$ catalyst was fixed, while the amount of $\mathrm{H}_{2} \mathrm{O}_{2}$ was varied to determine its optimum ratio. Ferrous ions react rapidly with $\mathrm{H}_{2} \mathrm{O}_{2}$ to produce a large amount of $\mathrm{HO} \cdot$ radicals (Equation 4). Based on the properties of this catalyst, only a small amount was required to speed up the reaction. Higher loadings of ferrous ions may only contribute to the waste of chemical.

$$
\mathrm{H}_{2} \mathrm{O}+\mathrm{Fe}^{3+}+h v \rightarrow \mathrm{HO} \bullet+\mathrm{H}^{+}+\mathrm{Fe}^{2+}
$$

Figure 7 shows the reduction of COD using dark Fenton, indoor photo-Fenton and solar photo-Fenton after $3 \mathrm{~h}$ of reaction time. Dark Fenton oxidation has contributed to COD reduction percentage that ranged between 20 to $45 \%$. The COD reduction efficiency was increased when the ratio of $\mathrm{H}_{2} \mathrm{O}_{2}$ concentration was increased from 1:10 to 1:30 for both indoor $(50-78 \%)$ and solar photo-Fenton $(62-89 \%)$ treatments. When the ratio was increased to 1:40, COD reduction efficiency had declined to $40 \%$ for indoor photo-Fenton and $56 \%$ for solar photo-Fenton. The excessive $\mathrm{H}_{2} \mathrm{O}_{2}$ loading could have resulted in the production of $\mathrm{HO}_{2} \bullet$ radicals, which are less productive, compared to $\mathrm{HO} \bullet$ radicals (Equation 5). $\mathrm{HO}_{2} \bullet$ radicals could also have formed with the incorporation of $\mathrm{HO} \bullet$ radicals in $\mathrm{H}_{2} \mathrm{O}_{2}$ (Equation 6). In addition, the $\mathrm{HO} \bullet$ radicals could have recombined to form $\mathrm{H}_{2} \mathrm{O}_{2}$, without favouring any reactions (Equation 7). Based on Figure 7, the reaction was concluded to be optimized when the $\mathrm{Fe}^{2+}: \mathrm{H}_{2} \mathrm{O}_{2}$ ratio was 1:30. With this ratio, the maximum percentages of COD reduction of $78 \%$ (from 73,000 to $16,000 \mathrm{mg} / \mathrm{L}$ ) and $89 \%$ (from 73,400 to $7,855 \mathrm{mg} / \mathrm{L}$ ) were obtained with indoor photo-Fenton and solar photo-Fenton treatments, respectively after $3 \mathrm{~h}$ of reaction time (Figure 8). A comparison of COD reductions between dark Fenton oxidation, solar photoFenton, and indoor photo-Fenton has shown that photon is necessary to activate the Fenton reagents. COD reduction using dark Fenton oxidation was rather low, although the trend was similar to those observed in the photo-Fenton treatments (indoor and solar).

$$
\begin{aligned}
& \mathrm{H}_{2} \mathrm{O}_{2}+\mathrm{HO} \bullet \rightarrow \mathrm{HO}_{2} \bullet+\mathrm{H}_{2} \mathrm{O} \\
& \mathrm{HO} \bullet+\mathrm{H}_{2} \mathrm{O}_{2} \rightarrow \mathrm{HO}_{2} \bullet+\mathrm{H}_{2} \mathrm{O} \\
& \mathrm{HO} \bullet+\mathrm{HO} \bullet \rightarrow \mathrm{H}_{2} \mathrm{O}_{2}
\end{aligned}
$$




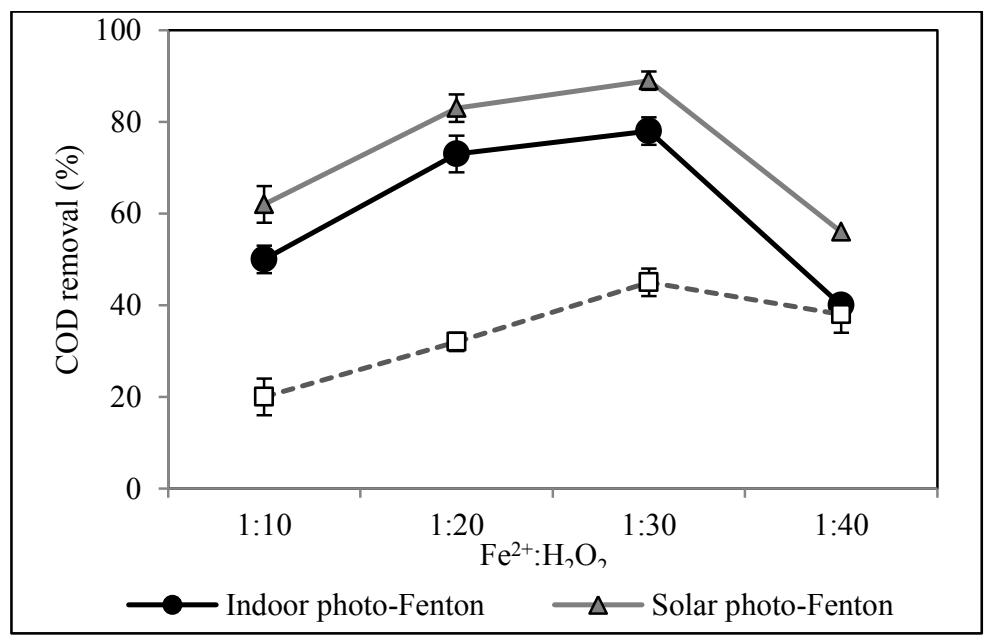

Figure 7. Reduction of COD by dark Fenton, solar photo-Fenton, and indoor photo-Fenton processes

In a Fenton treatment, $\mathrm{pH}$ plays an important role. The optimal $\mathrm{pH}$ condition in a Fenton reaction system is between 2.8 and 3.0 [28]. Therefore, the $\mathrm{pH}$ of POME solutions during each treatment was kept between 2.8 and 2.9. The purpose of the acidic $\mathrm{pH}$ is to avoid the precipitation of iron, which might interfere with the absorption of solar irradiation by the exposed medium. Prevention of iron precipitation will lead to the continuous photoreduction of ferric iron complexes at a longer wavelength.

In this study, solar photo-Fenton was found to be more efficient than indoor photo-Fenton. This result was in agreement with the findings reported by Aris et al. [17]. Several other studies have also concluded that solar photoFenton had performed better than other AOPs in various conditions, such as for textile effluent [29] and pharmaceutical wastewater [30]. The findings from the present study suggested that solar photo-Fenton should be considered as a valuable option for the reduction of COD in POME.

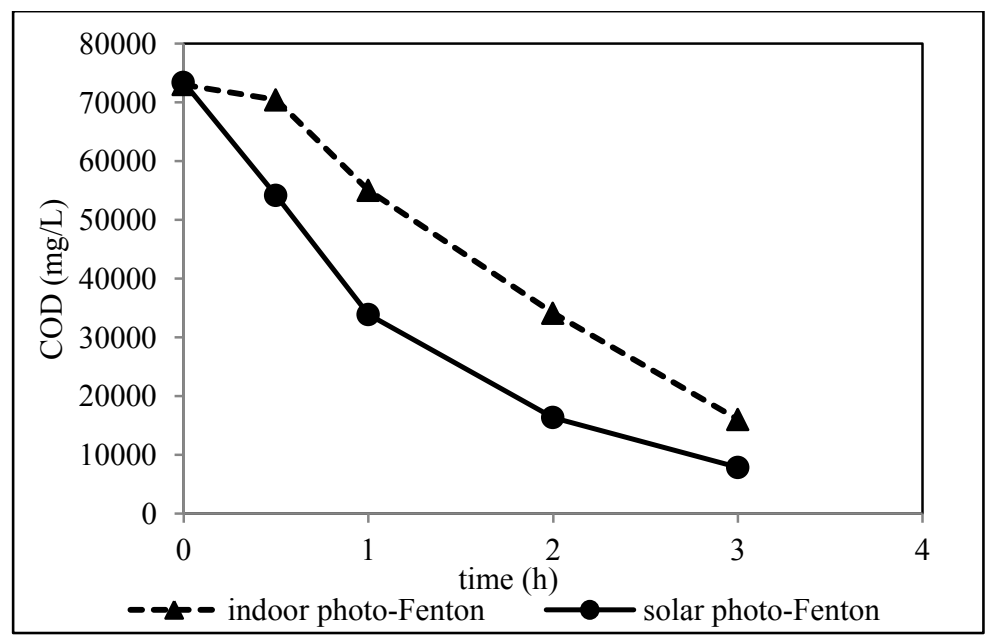

Figure 8. Reduction of COD by solar photo-Fenton and indoor photo-Fenton using the optimum $\mathrm{Fe}^{2+}: \mathrm{H}_{2} \mathrm{O}_{2}$ ratio $(1: 30)$ 


\section{Conclusion}

A higher percentage of COD reduction was accomplished with solar photo-Fenton compared to indoor photoFenton and dark Fenton under similar solar exposure time. The reduction of COD in POME was found to be governed by the concentration of the photocatalyst in solar $\mathrm{ZnO}$ and $\mathrm{TiO}_{2}$ photocatalysis. On the other hand, $\mathrm{H}_{2} \mathrm{O}_{2}$ concentration was the determinant for better solar photo-Fenton and indoor photo-Fenton treatments. In addition, the $\mathrm{pH}$ value in photo-Fenton systems has also played an important role, where the optimum $\mathrm{pH}$ value was found to be between 2.8 and 2.9. Decreasing the $\mathrm{pH}$ to 1.2 or increasing the $\mathrm{pH}$ to an alkaline level may result in poor COD reduction. Both solar photo-Fenton and solar $\mathrm{TiO}_{2}$ photocatalysis were able to produce up to $89 \%$ of COD reduction. Nevertheless, solar photo-Fenton took only $3 \mathrm{~h}$ of exposure time to achieve the highest reduction compared to solar $\mathrm{TiO}_{2}$ photocatalysis that took up to $5 \mathrm{~h}$ to achieve a similar level. This study has shown that the reduction of COD in POME generated from palm oil milling activities can be performed using solar photo-Fenton and $\mathrm{TiO}_{2}$ photocatalysis. Thus, solar photo-Fenton and $\mathrm{TiO}_{2}$ photocatalysis can be considered as pre-treatment steps prior to the biological treatment.

\section{Acknowledgement}

The authors would like to thank Mr. Krishan Singh, Mill Manager of Bau Palm Oil Mill Sdn Bhd, Sarawak, Malaysia for providing the samples. The authors would also like to acknowledge the financial support by the Ministry of Education Malaysia under the Research Acculturation Collaborative Effort programme [RACE/b(1)/1245/2015(01)] and the Fundamental Research Grant Scheme [FRGS/SG01 (01)/1204/2014(05)].

\section{References}

1. Wu, T. Y., Mohammad, A. W., Jahim, J. M. and Anuar, N. (2010). Pollution control technologies for the treatment of palm oil mill effluent (POME) through end-of-pipe processes. Journal of Environmental Management, 91(7): 1467 - 1490.

2. Ahmad, A. L., Ismail, S. and Bhatia, S. (2005). Optimization of coagulation-flocculation process for palm oil mill effluent using response surface methodology. Environmental Science \& Technology, 39(8): 2828 - 2834.

3. Ujang, Z., Salmiati, S. and Salim, M. R. (2010). Microbial biopolimerization production from palm oil mill effluent (POME). Institute of Environmental and Water Resource Management (IPASA), Universiti Teknologi Malaysia.

4. Setiadi, T. and Djajadiningrat, A. (1996). Palm oil mill effluent treatment by anaerobic baffled reactors: recycle effects and biokinetic parameters. Water Science and Technology, 34 (11): $59-66$.

5. Rupani, P. F., Singh, R. P., Ibrahim, M. H. and Esa, N. (2010). Review of current palm oil mill effluent (POME) treatment methods: vermicomposting as a sustainable practice. World Applied Sciences Journal, 11(1): $70-81$.

6. Legrini, O., Oliveros, E. and Braun, A. M. (1993). Photochemical processes for water treatment. Chemical Reviews, 93(2): $671-698$.

7. Soares, P. A., Silva, T. F., Manenti, D. R., Souza, S. M., Boaventura, R. A. and Vilar, V. J. (2014). Insights into real cotton-textile dyeing wastewater treatment using solar advanced oxidation processes. Environmental Science and Pollution Research, 21(2): 932 - 945.

8. Klavarioti, M., Mantzavinos, D. and Kassinos, D. (2009). Removal of residual pharmaceuticals from aqueous systems by advanced oxidation processes. Environment International, 35(2): $402-417$.

9. Kanakaraju, D., Motti, C. A., Glass, B. D. and Oelgemöller, M. (2014). Photolysis and $\mathrm{TiO}_{2}$-catalysed degradation of diclofenac in surface and drinking water using circulating batch photoreactors. Environmental Chemistry, 11(1): $51-62$.

10. Lucas, M. S., Peres, J. A., Amor, C., Prieto-Rodríguez, L., Maldonado, M. I. and Malato, S. (2012). Tertiary treatment of pulp mill wastewater by solar photo-Fenton. Journal of Hazardous Materials, 225: 173 - 181.

11. Babuponnusami, A. and Muthukumar, K. (2014). A review on Fenton and improvements to the Fenton process for wastewater treatment. Journal of Environmental Chemical Engineering, 2(1): 557 - 572.

12. Chong, M. N., Jin, B., Chow, C. W. and Saint, C. (2010). Recent developments in photocatalytic water treatment technology: A review. Water Research, 44(10): 2997 - 3027.

13. Lam, S. M., Sin, J. C., Abdullah, A. Z. and Mohamed, A. R. (2012). Degradation of wastewaters containing organic dyes photocatalysed by zinc oxide: A review. Desalination and Water Treatment, 41(1-3): 131 - 169. 
14. Vilar, V. J., Pinho, L. X., Pintor, A. M. and Boaventura, R. A. (2011). Treatment of textile wastewaters by solar-driven advanced oxidation processes. Solar Energy, 85 (9): 1927 - 1934.

15. Pereira, J. H., Reis, A. C., Queirós, D., Nunes, O. C., Borges, M. T., Vilar, V. J. and Boaventura, R. A. (2013). Insights into solar $\mathrm{TiO}_{2}$-assisted photocatalytic oxidation of two antibiotics employed in aquatic animal production, oxolinic acid and oxytetracycline. Science of the Total Environment, 463: 274-283.

16. Chekir, N., Benhabiles, O., Tassalit, D., Laoufi, N. A. and Bentahar, F. (2015). Photocatalytic degradation of methylene blue in aqueous suspensions using $\mathrm{TiO}_{2}$ and $\mathrm{ZnO}$. Desalination and Water Treatment, 57(13): 1 - 7 .

17. Aris, A., Siew, O. B., Kee, K. S. and Ujang, Z. (2008). Tertiary treatment of palm oil mill effluent using fenton oxidation. Malaysian Journal of Civil Engineering, 20(1): 12 - 25.

18. Ng, K. H. and Cheng, C. K. (2015). A novel photomineralization of POME over UV-responsive $\mathrm{TiO}_{2}$ photocatalyst: Kinetics of POME degradation and gaseous product formations. RSC Advances, 5(65): 53100 53110.

19. American Public Health Association (1999), American Water Works Association, Water Pollution Control Federation, \& Water Environment Federation. Standard Methods for the Examination of Water and Wastewater (Vol. 2). 18 ${ }^{\text {th }}$ Ed. American Public Health Association.

20. Carp, O., Huisman, C. L. and Reller, A. (2004). Photoinduced reactivity of titanium dioxide. Progress in Solid State Chemistry, 32(1): $33-177$.

21. Badawy, M. I., Gohary, F. E., Ghaly, M. Y. and Ali, M. E. M. (2009). Enhancement of olive mill wastewater biodegradation by homogeneous and heterogeneous photocatalytic oxidation. Journal of Hazardous Materials, 169(1): $673-679$.

22. Gaya, U. I. and Abdullah, A. H. (2008). Heterogeneous photocatalytic degradation of organic contaminants over titanium dioxide: a review of fundamentals, progress and problems. Journal of Photochemistry and Photobiology C: Photochemistry Reviews, 9(1): $1-12$.

23. Sakthivel, S., Neppolian, B., Shankar, M. V., Arabindoo, B., Palanichamy, M. and Murugesan, V. (2003). Solar photocatalytic degradation of azo dye: Comparison of photocatalytic efficiency of $\mathrm{ZnO}$ and $\mathrm{TiO}_{2}$. Solar Energy Materials and Solar Cells, 77(1): $65-82$.

24. Raj, K. and Viswanathan, B. (2009). Effect of surface area, pore volume and particle size of p25 titania on the phase transformation of anatase to rutile. Indian Journal of Chemistry, 48: 1378-1382.

25. Rojviroon, O., Rojviroon, T. and Sirivithayapakorn, S. (2014). Study of COD removal efficiency from synthetic wastewater by photocatalytic process. Environmental Engineering Research, 19(3): 255 - 259.

26. Vineetha, M. N., Matheswaran, M. and Sheeba, K. N. (2013). Photocatalytic colour and COD removal in the distillery effluent by solar radiation. Solar Energy, 91: 368 - 373.

27. Malato, S., Fernández-Ibáñez, P., Maldonado, M. I., Blanco, J. and Gernjak, W. (2009). Decontamination and disinfection of water by solar photocatalysis: recent overview and trends. Catalysis Today, 147(1): 1- 59 .

28. Oturan, M. A. and Aaron, J. J. (2014). Advanced oxidation processes in water/wastewater treatment: principles and applications. A review. Critical Reviews in Environmental Science and Technology, 44 (23): 2577 - 2641.

29. Manenti, D. R., Soares, P. A., Silva, T. F., Módenes, A. N., Espinoza-Quiñones, F. R., Bergamasco, R., Boaventura, R.A. and Vilar, V. J. (2015). Performance evaluation of different solar advanced oxidation processes applied to the treatment of a real textile dyeing wastewater. Environmental Science and Pollution Research, 22(2): $833-845$.

30. Klamerth, N., Rizzo, L., Malato, S., Maldonado, M. I., Agüera, A. and Fernández-Alba, A. R. (2010). Degradation of fifteen emerging contaminants at $\mu \mathrm{gL}^{-1}$ initial concentrations by mild solar photo-Fenton in MWTP effluents. Water Research, 44(2): 545 - 554. 